\title{
Remote-Control Circulation
}

A new circulation system was initiated in October 1964 at the University of Hawaii's Gregg M. Sinclair library. This article describes the system in general terms and sets it in the context of future automation plans at Hawaii. The unique aspect of the system is its use of IBM 1001 data collection devices, a remote control system for data transmission over telephone circuitry.

$\mathrm{O}_{\mathrm{r}}$

MAKING many circulation systems there appears these days to be no end. The one described here is primarily the work of Donald V. Black, now head of technical services at the University of California's Santa Cruz campus. This description is a preliminary one, to be supplemented by a more technical evaluation in the near future. In 1963 Black agreed to design an automated circulation system for the University of Hawaii's Gregg M. Sinclair library, one which would handle a rapidly-increasing workload while keeping personnel requirements from escalating in proportion. A little over a year later the system was installed and is now going through its first year of testing. Preliminary results reported from the circulation department are encouraging.

The operational principles on which the Hawaii system is based are similar to those underlying IBM's installations at Southern Illinois, Missouri, and Florida Atlantic. Two source documents, a machine-readable book card and a machinereadable borrower's card, are read serially to produce a transaction record, which then is transferred to magnetic tape at

Dr. Cammack is University Librarian, Oakland University, Rochester, Michigan. the computing center and processed as required to provide the desired loan information, overdue notices, and borrower lists. The unique aspect of the Hawaii system is its use of IBM's 1001 data collection units rather than the generally-preferred 357 units. The 1001 is a smaller, cheaper terminal which can transmit a limited amount of data over standard telephone lines to an $026 \mathrm{key}$ punch. The 357 unit requires regular cable connections. Both units will permit the keying-in of variable data as required, but only the 357 can be connected to multiplexing equipment allowing more than one terminal to transmit to a single keypunch. The 357 can transmit more information at a single reading than the 1001, and can handle two input documents (e.g., a punched card and a plastic borrower's card) at the same time rather than serially as is required by the 1001 . There is some latitude for adaptation of both units to local requirements, and from the borrower's point of view, there is little noticeable difference in transaction time or service potential.

\section{BORROWER IDENTIFICATION}

Students, faculty, staff, and off-campus borrowers at Hawaii are now provided with machine-readable identification 
cards. These are 51-column punched cards, designed to fold into a convenient wallet size. Off-campus borrowers' cards are prenumbered so they may be filled out and used by the borrower without delay. Student and faculty cards are prepared by the computing center and distributed at the beginning of each semester. While there is little question that a plastic badge capable of being both punched (for EDP input) and embossed (for printed records), is more flexible, the coordination of users' requirements proved difficult to accomplish in a short period of time. The punched card is probably easier and cheaper to replace, and no special updating systems are required. The new system has not been in operation long enough to tell whether or not card wear will be a problem. If so, issuing a new card should require only a few moments at one of the Circulation Department's keypunches.

\section{BOOK IDENTIFICATION}

Machine readable book cards are being prepared for each item as it circulates for the first time under the new system, and for all new additions to the collection. Fifty-one-column book cards are punched with the complete call number, a collection code, and a loanperiod code. Short author and title information is also printed on the card for ease of identification, but not punched because of the shortened format of the card. Book cards are prepared on continuous form stock by the computing center from punched card information originating in the circulation and catalog departments.

Several other systems are now available for the production of machine-readable book records, including the use of service bureaus working from shelflist cards or microfilm copies thereof. The "do-it-themselves" decision at Hawaii has shown some disadvantages but has served to acquaint the staff more thoroughly with the workings of punched card equipment while offering more flexibility during the experimental stages. It is interesting to note that while two additional keypunch positions were authorized for the switch-over period, it proved impossible to fill them in time to be of much use. With only a week's training, two members of the circulation department's clerical staff took over the job and have managed through heroic efforts to keep up with the daily requirements of the new system. Their creative ideas have been responsible for several important refinements in the system's implementation and operation.

\section{To Borrow A Book}

To borrow a book which has already circulated through the new system, the borrower brings the book to the main circulation desk and presents it, with his personal identification card. The desk attendant inserts the borrower's card in the 1001 and slides the carriage into reading position. The information is read and transmitted in about three seconds to an 026 keypunch located in the circulation department work area where its chatter does not disturb library users. Next, the attendant removes the borrower's card and inserts the book card in the 1001 for reading in the same fashion. A system which retains certain punch codes will permit the charging of a number of books to the same borrower without reinserting the borrower's card each time. The attendant returns the book card to its pocket and the borrower's card to the borrower, inserts a datedue slip in the pocket, and the transaction is complete.

Meanwhile, back at the keypunch, a single transaction card has been automatically produced for each book borrowed. Over telephone circuits, the electronic impulses from the 1001 have been translated into audio impulses and sent to the keypunch where they were retranslated to electronic impulses which the machine could recognize. The result 
is a transaction card with information arranged as follows.

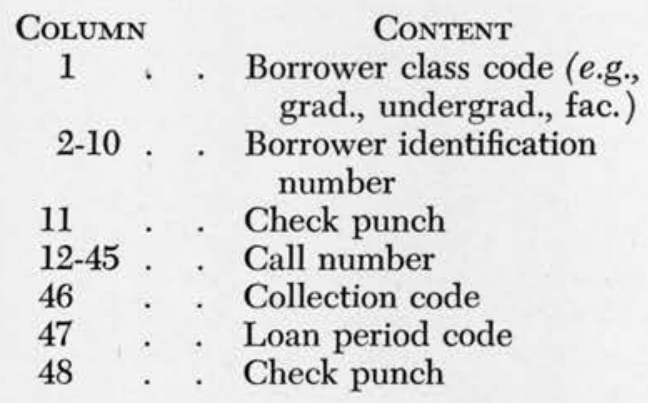

The machines are equipped so that operator errors or faulty transmissions produce a tone signal to inform the operator that the process must be repeated correctly. Any mechanical failures are also brought quickly to the attention of the operator. If a borrower does not have his card and can identify himself to the satisfaction of the desk attendant, the borrower's number can be keyed in manually on the 1001, thus avoiding any service delay. A duplicate set of borrower registration cards could also be maintained at the desk if desired.

\section{Computing Center Service}

The transaction cards, each carrying their book and borrower information, are sent to the statistical and computing center daily, where they are read into the computer, sorted into call number sequence and added to the master record of books on loan. A daily printout of this regularly updated record is returned to the library where it takes the place of all the manually filed card records which once occupied the department's staff both day and night.

Faculty and other long term loans are separated weekly from the daily loan record and added to a separate listing to reduce over-all processing time and the necessity of repeatedly processing inactive records. Preparation of overdue notices, calculation of fines, and all circulation statistics are also handled by the computer (a 1401 plus 7040 con- figuration with off-line printing capabilities). The general estimate of daily processing time was calculated to be less than an hour a day.

\section{To Return a Book}

The borrower need only deposit a returned book in one of the library's regular return bins. The discharging process again involves a machine operation. A student assistant removes the book card and inserts it in the 1001 near the discharge area. This device is also connected by telephone lines to a keypunch in exactly the same manner as the charging machine, and may be used interchangeably with it in case of overload or machine failure. In place of a borrower's card the machine is "primed" with a general return card and requires only that the book cards for returned books be placed in the carriage and read. When the carriage returns to its original position, the student cancels the date due slip, inserts the book card, and the volume is ready for shelving. The return transaction cards go to the computing center and are processed with the charge cards, thus clearing the master loan record daily.

\section{Overdues, Renewals, and Holds}

Overdue books returned to the bin without notification are identified by the computer and fine notices prepared automatically. When a borrower returns an overdue book and offers to pay the fine, it is collected and a "paid" slip is inserted in the pocket. In discharging "paid" books, the 1001 is primed with a special card and the borrower's ID number is added later at the computing center to assure credit to the right "account," and a proper clearing of the master loan record. Fines for unreturned books are cumulated automatically and notices sent periodically.

Renewals are handled like new loans after ascertaining that there is not a "hold request" for the item. The com- 
puter counts the number of renewals and thus prevents the possibility of abuse of the privilege by indicating on the daily printout the number of times a book has been charged out to the same borrower.

A two part "Hold Request" card can be filled out by the borrower with author, title, and borrower's ID number. Of the several possible systems for seeing that a book wanted by a specific borrower does not get back on the shelves, two were proposed for testing. The first is a simple adaptation of the old "dummy" system, whereby cardboard dummies are shelved in the appropriate spot in the stacks, and returned books with "hold requests" are stopped at the shelving point and returned with the dummy to the circulation department. There, the stub of the hold request is sent to the requester and the rest of the card shelved with the book on special hold shelves for a stipulated length of time.

A second "matching" system has been recommended, whereby hold-request forms are punched with the book information and machine matched against return transaction cards several times each day before books leave the sorting shelves for the stacks. Holds are then pulled and processed as described above.

\section{Faculty and Long-Term Loans}

Faculty members at the University of Hawaii are accustomed to a semesterlong loan period with renewal privileges for another semester. Discounting summer-session loans, this means that faculty are required to return all library books in their possession only once a year. Since faculty members account for some 50 per cent of all loan transactions, it is not difficult to see that, for many of them, it is difficult at the end of a semester to know exactly what library books are charged to them. A faculty delegate system adds to the potential confusion when return time comes around.

With the new system, it is possible at the end of each semester to machine-list all titles on loan to a faculty member and to send the list to him with a request to return all unwanted items and to note those for which renewal is requested. It is hoped that this reminder system will at least limit the tendency of a portion of the faculty to build large office "libraries" at the expense of students and other would-be borrowers. The ability to print out all items on loan to a given borrower should also facilitate the clearing of records for graduating students and others who leave the university.

Listing of books on long term loan to the reserve room are also subject to callnumber arrangement and to virtually any other useful permutation. The necessity of maintaining a separate reserve room catalog is therefore eliminated, along with the traditional lag imposed by large periodic increases in workload.

\section{Lost Books AND SNAgS}

A book reported lost or destroyed can be cleared from the master loan record by punching and running a duplicate card through the return transaction card system. (Books returned without cards can be treated in much the same fashion.) Search procedures for snags are essentially unchanged under the new system, although it is now possible to assign a "missing" code and list all such items on the master loan record by running the card through the charging system. The same technique covers items out to mending, binding, and interlibrary loan.

\section{Statistics}

The hours spent preparing daily circulation statistics are now a thing of the past. Daily figures appear on the master loan record and are automatically cumulated to produce monthly and quarterly reports. It was further recommended that all charge transaction cards be kept for at least one semester. These cards 
can then be sorted to ascertain areas of heavy use, titles in short supply, possible titles for a proposed undergraduate library, and so forth. If matched against borrower number, reading profiles on individuals or specific groups can also be obtained. If eventually combined with registration records, it would be possible to discover whose students in what courses read what and how much of it. A great deal of such information can be machine produced as the needs and interests of faculty and administration develop. From the library's point of view, for instance, automatic reorder records could be set by merely establishing the number of circulations for a given title, above which added copies would be automatically ordered.

\section{SySTEM Expansion}

When the circulation system described above was approved for implementation by the university administration and the state department of budget and finance's statewide data processing organization, it was anticipated that the system would be immediately expanded to include order department routines and coordinated with certain book preparation operations in the catalog department. With these plans in mind, two 826 typewriter-keypunches were installed in the order and catalog departments respectively. Serials records were to be considered separately in connection with a new edition of the Hawaii Library Association's Union List of Serials.

The initial function of the catalog department's 826 was to produce machinereadable book cards as a by-product of typing book pockets. The information on both could be easily coordinated, and training of staff to use the simple typewriter-keypunch combination presented no problem. The creation of a machinereadable shelflist card was deferred pending experiments with other depart- ments and the results of national activities in this direction.

The automation of order department routines is already flow-charted and approved. Personnel vacancies have delayed the expected implementation date, but the advantages and experience gained in the circulation operation will contribute significantly to the effectiveness of this aspect of the proposed total system. A system for punched-card handling of a certain portion of serials records has been suggested, and it is hoped that implementation of some machine handling of these records will not be long delayed.

\section{System Costs}

The system is not yet fully operative, and perhaps more than a year will be required before accurate cost figures will be available. It was designed to operate at approximately the same cost as the unsatisfactory manual system which preceded it, not taking into consideration any expansion into departments other than circulation. A $\$ 25,000$ switchover budget was approved, and at this writing it appears that a large portion of this amount will be returned to the state at the end of the fiscal year. Machine costs turned out to be considerably lower than expected as a result of unpredictable advantages gained through cooperative use of certain items. Telephone equipment, however, exceeded the expected amount. Though not altogether as a result of library planning, it may well turn out that all extra personnel costs, including consultant fees, will have been absorbed within the general operating budget, thus leaving the library in a position to state that the new system literally paid for its own implementation and operation. Significant savings are expected to accrue over an extended period of time as workload increases are absorbed by machines rather than by additional staff. These "savings," however, are far less important to the 
library, its staff, and its users than are the time saving advantages of a really efficient, reliable, circulation system.

\section{Hawan's Automation Potential}

Few states in the country offer the vast potential for improved library service through creative use of data processing equipment that Hawaii provides. A relatively small population and a highly centralized state system of education and library service hold extraordinary opportunities for librarians to experiment with, select, and establish high standards of service and facilities for formal educational goals and for waging a War on Ignorance proposed by President Johnson. A Governor's Committee on State Library Resources has recently submitted a report in which a number of proposals are made for the further coordination of library activities in Hawaii. Already, under the office of the state librarian, a centralized processing center handles ordering and cataloging for some schools and for the Library of Hawaii. A punched card system for this center was recently implemented and should be transferred to a computer system within the near future. A Union List of Serials is nearing completion, and is scheduled for computer processing. Computer-produced book catalogs are under consideration for the statewide public library system, and a proposal has been made to work with the Supreme Court law library toward putting certain portions of the state's laws on magnetic tape, following examples already set in several mainland states. With the coordinating guidance of the state librarian, it should be possible to expand the beginnings now made toward a total, integrated statewide information system of extremely advanced conception and design. The resultant advantages to state government, to research interests, and to educational institutions would be virtually incalculable.

\section{ALA Headquarters Library Loan Service}

THE ALA HEADQUARTERS LIBRARY has been designated as a working collection for the staff of ALA headquarters by the ALA Executive Board. It has, however, offered several services directly to the members through interlibrary loan. Among them is a collection of library handbooks, procedure and policy manuals and surveys. These have been given to the library over the years by the college and university libraries which prepared them. To keep the collection up to date and more helpful to the libraries which borrow the manuals, the library has asked that college and university libraries make their manuals available to others by depositing one copy in the ALA headquarters library, 50 E. Huron St., Chicago, Ill. 60611. Each library can be sure that it would then be sharing its materials with those libraries needing them.

Those libraries which are interested in borrowing manuals should send a standard ALA Interlibrary Loan Request form for each manual or survey it wishes to borrow. 